\title{
Environmental assessment of forestry in Canada
}

\author{
by Steve Bonnell ${ }^{1}$
}

\begin{abstract}
Environmental assessment (EA) is widely used as a means of identifying and addressing the potential environmental effects of proposed development activities. This paper provides an overview of EA and its application to forest management in Canada. Forestry planning processes in Canada generally include consideration of environmental issues and stakeholder participation, and therefore incorporate key aspects of EA as part of the planning exercise. EA review can, however, provide an opportunity to further assess and consider the potential environmental effects of proposed forestry activities, as required, as well as involve other relevant parties in decision-making.
\end{abstract}

Key words: environmental assessment, forest management, planning, Canada

L'évaluation environnementale (EE) est couramment utilisée en tant que moyen pour identifier et aborder les effets environnementaux potentiels découlant des activités proposées de développement. Cet article constitue un survol de l'EE et de ses applications en matière d'aménagement forestier au Canada. Les processus de planification forestière au Canada incorporent habituellement l'étude des questions environnementales et la participation des intervenants, et en par le fait même, incluent les principaux aspects de l'EE en tant qu'élément de l'exercice de planification. Une revue de l'EE peut, cependant, constituer une opportunité pour évaluer et étudier plus en détail les conséquences environnementales potentielles des activités forestières proposées, tel que requis, ainsi qu'impliquer d'autres groupes affectés dans le processus de décision.

Mots clés: évaluation environnementale, aménagement forestier, planification, Canada

\section{Introduction}

Environmental assessment (EA) is a systematic process for analyzing and evaluating the potential environmental effects of proposed development activities. In the over three decades since its introduction, it has become widely used as a means of integrating environmental considerations into development planning and decision-making, and is recognized as an important tool for promoting sustainable development. EA has been adopted in more than 100 countries (CEA Agency 1999), and is applied to a wide range of projects, including forest management activities.

This paper provides a brief overview of EA and its application to forestry in Canada. It goes on to explore a number of issues and perspectives regarding the need for, and use of, EA in the context of forest management planning.

\section{Environmental Assessment in Canada}

EA had its origin with the passage of the National Environmental Policy Act in 1969 in the United States, with other countries introducing similar requirements soon after. In Canada, the Environmental Assessment and Review Process (EARP) was established through a 1973 cabinet directive. The process was updated in 1977, and formalized in 1984 when the EARP Guidelines were issued by order-in-council. Subsequent efforts to reform the process eventually resulted in the proclamation of the Canadian Environmental Assessment Act (CEAA) in 1995, which currently forms the legislative basis for federal EA in Canada.

$C E A A$ applies to projects that involve the federal government. The Act requires federal authorities to undertake an EA for proposed projects for which they are the proponent, or before they provide financial assistance, land or certain authorizations to enable a project to go forward. EA processes have also been established in each of Canada's provinces and territories (Table 1) which, although similar in overall purpose, differ some-

1Jacques Whitford Environment Limited, 607 Torbay Road, St. John's, Newfoundland and Labrador A1A 4Y6. E-mail: s.bonnell@ roadrunner.nf.net what in terms of their specific nature and application. Other public and private-sector organizations in Canada have also adopted EA procedures for project planning and review (Dupuis and LeBlanc 1995). In cases where two or more EA processes apply to a proposed project, a "harmonized" assessment may often be conducted that meets the requirements of each process while avoiding unnecessary duplication.

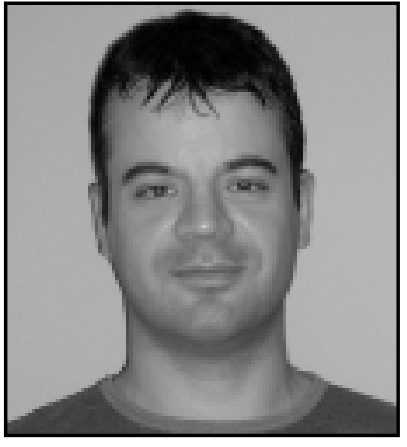

Steve Bonnell
Through EA, the potential environmental effects of a proposed project can be identified early, and, therefore, considered in decisions regarding its implementation. Although the nature of the process differs according to jurisdiction and the type of assessment being conducted, EA generally involves the following:

i) Screening: Determining whether a project requires an EA, and if so, the level of assessment needed.

ii) Scoping: Identifying the key environmental issues of concern, upon which the EA will focus. This may involve consultation with relevant government agencies, organizations and/or the public.

iii) Effects Analysis: A description of the existing (baseline) environment and an assessment of the potential environmental effects of the project.

iv) Mitigation: The identification of measures to eliminate or reduce adverse effects, or to optimize any positive effects (e.g., buffer zones, local hiring policies).

v) Effects Evaluation: Determining the significance of the project's remaining, residual environmental effects.

vi) Follow-Up: Monitoring may be proposed to ensure compliance with environmental regulations, and/or to verify effects predictions and the effectiveness of mitigation. 
The results of an EA are used by decision-makers to determine the environmental acceptability of a proposal, and ultimately, whether it may proceed (often with conditions).

\section{Environmental Assessment and Forestry}

Table 1 provides an overview of Canadian federal and provincial/territorial EA processes and their application to forest management activities.

In general, the application of the federal EA process to forestry has been relatively limited, since forest planning and management fall mainly under provincial jurisdiction (Dunster 1992). In 2002, approximately 140 forestry-related projects were assessed under CEAA (CEA Agency 2003). The process is triggered primarily when particular aspects of a forestry operation require federal approval (e.g., bridge installations for a forest access road).

The application of provincial and territorial EA processes to forestry varies considerably (Table 1). In a number of provinces, EA does not apply to forest management activities that are covered under specific provincial forestry legislation (e.g., British Columbia, Québec). In others, forestry activities are not specified as being subject to (or exempt from) EA (e.g., New Brunswick, Alberta). In most such cases, forestry activities are generally not subject to assessment. There may, however, be Ministerial discretion to require EA for any proposal that may have significant adverse effects, and/or for which there is considerable public concern. Particular aspects of proposed forestry operations may also indirectly trigger EA requirements (e.g., access roads, activities affecting wetlands or other sensitive environmental features). In some jurisdictions, proposed development activities of any type are screened (when, for example, required permits are applied for), and a determination is made whether further EA is required (e.g., the Northwest Territories, Nunavut). In several provinces, however, the EA process applies specifically to individual forestry activities (such as cutting operations, roads, or spray programs) and/or to overall forest management plans (e.g., Manitoba, Saskatchewan) (Table 1).

In Newfoundland and Labrador, for example, five-year forestry operating plans for the province's forest management districts require registration under the province's EA process. Plans must be submitted to the Department of Environment not less than 180 days before their proposed commencement date, and are subject to review by government agencies and the public. The Minister of Environment then decides whether the undertaking may proceed (subject to the requirements of other applicable legislation), is rejected, or whether further assessment is required. If a registration contains insufficient information to make this determination, an Environmental Preview Report (EPR) may be required, which provides more information on the proposal and its potential environmental effects. If the review of a registration or EPR indicates that significant environmental effects may occur, or where there is significant public concern, an Environmental Impact Statement (EIS) may be required, which provides a detailed description of the undertaking and its potential effects. Public hearings may also be held if there is strong public interest or concern regarding a proposal.

In 2002, 10 forestry operating plans, and 11 proposed amendments to plans, were registered under Newfoundland and Labrador's EA process (NLDOE 2003). Most plans are subsequently released from the EA process without requiring further, more detailed assessment, although release may be subject to conditions identified during the registration review (e.g., no cutting zones, road realignments, monitoring). A number of proposed plans have required further EA, however, such as recent proposals for forestry operations in the Main River area of west-central Newfoundland.

A number of EA processes in Canada include provisions for "class EA," which is used to streamline the assessment of projects that are considered relatively small-scale and/or routine, and that have the potential for predictable and mitigable environmental effects. Class EA usually involves a single, detailed assessment for a type of activity. Once this assessment is approved, subsequent projects within the class may not require individual EA review. Although not yet widely used in most of Canada, class assessment has the potential to considerably improve the efficiency of the EA process for specific sectors. In Ontario, a class EA approach has been applied to forest management on crown lands. The Timber Class EA Approval was granted in May 1994 after extensive public hearings, and covers a range of recurring forest management activities, including timber harvesting, road construction and forest renewal activities. It outlines a planning process for forest management, which, when adhered to, allows forestry activities to proceed without requiring further approval from the Minister of the Environment. Stakeholders may, however, request that specific forest management activities be "bumped-up" to an individual EA if required (OMNR 2003). In July 2003 the Minister of the Environment issued a Declaration Order that extended and amended the Class EA Approval.

\section{Why Apply Environmental Assessment to Forestry?}

Even where EA processes apply to forestry, the relationship between forest management planning and EA is often not particularly well defined, nor are the potential benefits of EA review always recognized.

Forestry planning processes in Canada generally include consideration of environmental issues, and involve considerable stakeholder input. They therefore incorporate key aspects of $\mathrm{EA}$ as an integral part of the planning exercise. Again using the example of Newfoundland and Labrador, forest management plans for each management district are prepared through a consultative process, which involves a planning team comprised of government, industry and interested organizations and individuals. The principles of sustainable development and environmental protection are key considerations in this planning process (Moores and Duinker 1998, Nazir and Moores 2001). It has been suggested by some that the potential environmental effects of forest management can therefore be adequately dealt with by the forestry community itself, without requiring EAs of proposed forestry operations (e.g., Taylor 1990).

Forestry planning processes such as these allow environmental issues to be identified early, and, therefore, considered proactively in the development of forest management plans. In many cases, potential environmental effects can indeed be addressed most effectively through such processes, as well as through the various regulations, standards and guidelines that typically apply to forestry activities. EA is not intended as a substitute for good planning, or the consideration of environmental issues within these processes. Rather, EA can provide an opportunity for the results of forest management planning 
Table 1. Canadian federal and provincial / territorial environmental assessment processes and their application to forest management

\begin{tabular}{lll}
\hline Jurisdiction & EA Legislation & Application to Forest Management Activities \\
\hline Canada & Canadian Environmental Assessment Act & $\bullet$ Applies to forestry projects which require a federal decision (proponent, \\
& and associated Regulations (e.g., Comprehensive & funding, land and/or certain permits).
\end{tabular}

Newfoundland Environmental Protection Act,

and Labrador Environmental Assessment Regulations

Nova Scotia Environment Act,

Environmental Assessment Regulations,

Environmental Assessment Board

Regulations

Prince Edward Environmental Protection Act

Island and Guidelines

New Brunswick Clean Environment Act, Environmental

Impact Assessment Regulation

Québec Environment Quality Act, and associated Regulations (EA regulations for Southern Québec, the Territory of James Bay and Northern Québec and for a part of the Northeastern Québec Region).

James Bay and Northern Québec Agreement and the Northeastern Québec Agreement

Ontario

Environmental Assessment Act and associated Regulations

Manitoba Environment Act,

Classes of Development Regulation and other associated Regulations

Saskatchewan Environmental Assessment Act

Alberta Environmental Protection and Enhancement Act, Environmental Assessment (Mandatory and Exempted Activities) Regulation, Environmental Assessment Regulation

British Columbia Environmental Assessment Act, Concurrent Approval Regulation, Prescribed Time Limits Regulation, Public Consultation Policy Regulation, Reviewable Projects Regulation, Transition Regulation

Yukon

Environmental Assessment Act and associated Regulations (New legislation and regulations which closely mirror CEAA. Transition to the Development Assessment Process (DAP) under the Umbrella Final Agreement).

Northwest Territories

Mackenzie Valley Resource Management Act and associated Regulations (Applies to all of the NWT except the Inuvialuit Settlement Region (ISR) and Wood Buffalo National Park. $C E A A$ no longer applies in the Mackenzie Valley, except in very specific situations).

Inuvialuit Final Agreement, Western Arctic (Inuvialuit) Claims Settlement Act (The ISR is located to the northwest of the Mackenzie Valley).

- Applies to projects that require a Yukon government decision (proponent, funding, land and/or certain permits).

- Regulatory authorities conduct a preliminary screening of project proposals Those with the potential for significant adverse effects and/or public concern are referred to the Mackenzie Valley Environmental Impact Review Board for further assessment.

- Some small-scale timber harvesting may be exempt under certain conditions.

- Proposed projects on crown lands within the ISR are screened by the Environmental Impact Screening Committee. Projects may then be referred to the Environmental Impact Review Board for further EA review. Projects on Inuvialuit-owned lands may also be screened, depending on the decision of the Inuvialuit Land Administration.

Nunavut Nunavut Land Claims Agreement (Article 12)

- Proposed projects within the Nunavut Settlement Area requiring land or water use authorizations are referred to the Nunavut Impact Review Board for screening and possibly further EA review.

Note: Table provides general, summary information only. EA legislation and guidelines should be consulted for information on specific requirements and processes 
to be subject to an "arms-length," in-depth and systematic environmental review. It can allow for a final "environmental check" and decision regarding the environmental acceptability of a proposed plan prior to its implementation. EA also allows a range of government agencies and stakeholders, including those that may have an interest, but were not directly involved in the planning exercise, to review the proposal and participate in decisions regarding it.

Notwithstanding the potential benefits of EA, it is, however, important that it be applied efficiently, with proposals subject to an appropriate level of analysis. Concern has been raised in some areas regarding the time and resources that would be required to conduct detailed EAs for all forestry operations. The purpose of assessing proposed forestry activities in some areas where similar operations have been on-going for years has also been questioned.

EA processes typically include a "screening mechanism," through which projects are subject to an initial environmental review by government and stakeholders. This provides an opportunity for these agencies, organizations and/or individuals to participate in decision-making, while at the same time ensuring that only those proposals with the potential for significant environmental effects are subject to further, detailed assessment. In the case of forestry, this may include, for example, proposed operations in particularly sensitive areas, or those involving fundamental changes in management strategies or practices that may have important environmental implications. The use of class assessments (with "bump-up" provisions), such as in Ontario, can also enhance the efficiency of the EA process.

\section{Summary}

EA processes in Canada vary considerably in their application to forestry. The need for, and potential benefits of, EA review are very much activity-, area- and process-specific. Forest management planning processes in Canada typically incorporate key aspects of EA as part of the planning exercise. Good planning and environmentally sound operating practices will continue to be the most important means of addressing the potential environmental effects of forestry. EA can, however, provide an opportunity to further assess and consider the potential environmental effects of proposed forest management activities, as required, as well as involve other relevant agencies and stakeholders in the decision-making process.

\section{References}

CEA Agency (Canadian Environmental Assessment Agency). 1999. Review of the Canadian Environmental Assessment Act: A Discussion Paper for Public Consultation. http://www.ceaa-acee.gc.ca CEA Agency (Canadian Environmental Assessment Agency). 2003. Federal Environmental Assessment Index. http://www.ceaa-acee.gc.ca (Note: Index was searched for EAs of projects for which "forestry" is given as the subject descriptor).

Dunster, J. 1992. EIA and forestry: A review. Environments. 21(3): 26-38.

Dupuis, S. and P. LeBlanc. 1995. Directory of Environmental Assessment Practices in Canada. Canadian Environmental Assessment Agency, Hull, QC.

Moores, L. and P.N. Duinker. 1998. Forest planning in Newfoundland: Recent progress with public participation. The Forestry Chronicle. 74(6): 871-873.

Nazir, M. and L.J. Moores. 2001. Forest policy in Newfoundland and Labrador. The Forestry Chronicle. 77(1): 61-63.

NLDOE (Newfoundland and Labrador Department of Environment). 2003. $h t t p: / / w w w . g o v . n l . c a / e n v$

OMNR (Ontario Ministry of Natural Resources). 2003. Forest Management Class Environmental Assessment. http://ontariosforests.mnr. gov.on.ca/timbereaoverview.cfm

Taylor, J. 1990. Sustained timber production. In Technical Proceedings of the $34^{\text {th }}$ Annual Meeting of the Canadian Institute of Forestry, November 22-24, 1990, St. John's, NL. 